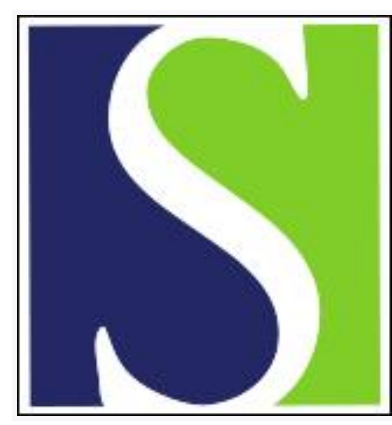

Scand J Work Environ Health 1997;23(2):93-103

https://doi.org/10.5271/sjweh.186

Issue date: Apr 1997

Asbestos, asbestosis, pleural plaques and lung cancer

by Hillerdal G, Henderson DW

The following article refers to this text: $2004 ; 30(3): 206-214$

Key terms: asbestos; lung cancer; lung fibrosis; pleural plaque

This article in PubMed: www.ncbi.nlm.nih.gov/pubmed/9167232

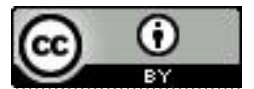




\title{
Asbestos, asbestosis, pleural plaques and lung cancer
}

\author{
by Gunnar Hillerdal, MD, ${ }^{1}$ Douglas W Henderson, MRC Path ${ }^{2}$
}

\begin{abstract}
Hillerdal G, Henderson DW. Asbestos, asbestosis, pleural plaques and lung cancer. Scand $J$ Work Environ Health $1997 ; 23(2): 93-103$.

Inhalation of asbestos fibers increases the risk of bronchial carcinoma. It has been claimed that asbestosis is a necessary prerequisite for the malignancy, but epidemiologic studies usually do not have enough statistical strength to prove that asbestos-exposed patients without asbestosis are without risk. Several recent studies do actually indicate that there is a risk for such patients. In addition, case-referent studies of patients with lung cancer show an attributable risk for asbestos of $6 \%$ to $23 \%$, which is much higher than the actual occurrence of asbestosis among these patients. Thus there is an increasing body of evidence that, at low exposure levels, asbestos produces a slight increase in the relative risk of lung cancer even in the absence of asbestosis. Consequently, all exposure to asbestos must be minimized.
\end{abstract}

Key terms asbestos, lung cancer, lung fibrosis, pleural plaques.

The main cause of lung cancer is smoking. However, inhalation of asbestos fibers can increase the risk for this tumor considerably. The first reports of lung cancer in connection with exposure to asbestos all concerned patients with asbestosis (ie, pulmonary fibrosis caused by asbestos) (1-4). The German physician Nordmann was, in 1938 , one of the first to suggest that lung cancer in asbestosis was an occupational disease, and he assumed that the tumor resulted from the proliferating alveolar and epithelial cells in the fibrotic lung (2). Thus, from the outset, it was assumed that the cancer was caused by the fibrosis, not the asbestos fiber in itself ("the asbestosis-cancer hypothesis"). In 1943 the German government declared lung cancer associated with asbestosis to be an occupational disease. It took another 20 years to reach the same conclusion in the United States (5).

Over the years, many researchers have remained in favor of "the asbestosis-cancer hypothesis" (6-13). Gradually, however, several papers have appeared which have shown that an increased risk for lung cancer occurs also in asbestos workers without obvious asbestosis. This finding has led to the proposition that it is the asbestos fibers, not the asbestosis, that are responsible for the tumor ("the asbestos-cancer hypothesis"). As a consequence, a linear dose-response relationship was assumed between asbestos and lung cancer (14-40). However, no consensus has yet been reached on whether lung fi- brosis is an obligatory precursor to asbestos-related lung cancer or not.

The purpose of this review is to examine some of the statements made by the two factions and the findings often statistically weak - that lie behind these claims. First, some basic facts must be remembered.

\section{Latency time}

The risk of carcinoma is very low or undetectably low for the first 10 years after exposure to asbestos, but it gradually increases and is highest after more than 30 years $(17,34,41-43)$. According to some studies, exposure to low doses will not only produce fewer cancers, but also possibly longer latency times than high doses (44). Consequently, long-time follow-up is necessary, or a number of cancers can be missed and risk evaluation will be flawed (36).

\section{Type of asbestos}

The main types of asbestos are those consisting of straight fibers (amphiboles), of which the most important

1 Department of Lung Medicine, Karolinska Hospital, Stockholm, Sweden.

2 Department of Histopathology, Flinders Medical Centre, Bedford Park, Adelaide, South Australia.

Reprint requests to: Dr Gunnar Hillerdal, Department of Lung Medicine Karolinska Hospital, S-17176 Stockholm, Sweden. 
are crocidolite, amosite, tremolite and anthophyllite, and those with curly fibers, of which there is only one important type, namely, chrysotile. These fibers all differ in their diameters and lengths and also in their ability to resist breakdown in biological tissues. Chrysotile is by far the most widely used. It also has the fastest clearance from the body, probably due to its higher solubility. As a consequence, in workers' lungs at autopsy, when the exposure occurred some decades earlier, the most commonly found fibers are amphiboles, even if the exposure had been predominantly chrysotile asbestos.

Possibly for this reason, amphiboles seem to carry a greater risk for mesothelioma than does chrysotile $(7,27$, 45). As for lung cancer, however, a recent review has concluded that there is little evidence to indicate lower lung cancer risk (46). To confuse matters even more, there are differences between diameters and lengths of the same type of asbestos, the result being different risks for the various diseases. For example, very long chrysotile, as was used in the textile industry, results in a considerably higher risk for cancer than does the "normal" short-fibered chrysotile (27).

\section{The "threshold value"}

The existence of a threshold value below which no excess lung cancer occurs has been suggested $(9,11)$. On the other hand, there are claims that even low doses of asbestos can increase the risk $(20,30,31,34,44$, $47-51$ ). In several studies, it has been shown that exposure to a low dose of pure chrysotile (less than 20 fiberyears) causes no measurable increase in lung cancer (25, 52-55).

However, it should be remembered that the effects of exposure to low doses of carcinogens are very difficult to measure and even more problematic to prove statistically, because very large cohorts are needed $(40,56,57)$. Failure to prove statistically an excess of any disease with a low risk does not prove that such an excess does not exist, epidemiologic studies are simply not sensitive enough (58). This basic epidemiologic truth is too often forgotten.

Of course, if one subscribes to "the asbestosis-cancer hypothesis", a threshold is automatically implicated (since a fairly high exposure is necessary for asbestosis to develop); on the other hand, "the asbestos-cancer hypothesis" is compatible both with a threshold and without a threshold.

\section{Smoking habits}

Smoking and exposure to asbestos have synergistic effects on lung cancer risk. It seems that a multiplicative model fits the data best $(21,31,34,43,59,60)$. Consequently, correction for smoking habits must be made in all comparisons concerning risks of lung cancer. However, in the real world, the differences in smoking habits between various occupational groups in the same society are not very great, and a relative risk in excess of 1.4 is unlikely to be due to such differences (61).

\section{Increased risk of lung cancer in other types of lung fibrosis in man}

Proponents of "the asbestosis-cancer hypothesis" have drawn attention to the fact that other types of fibrosis in humans (eg, idiopathic, other pneumoconioses, and those that occur in collagen diseases) also have an increased incidence of lung cancer. In fact, it is mainly in systemic sclerosis (62) and cryptogenic fibrosing alveolitis (63, 64) that any larger number of lung cancers are found. The risk of lung cancer in silicosis is also moderately increased (relative ratio 3.4 for smokers with silicosis and 1.7 for nonsmokers) (65-67). Whether this increased risk is due to the silicosis or to the silica particle itself is another problem.

The typical cancers in systemic sclerosis are peripheral adenocarcinomas or bronchioalveolar cell carcinomas (62), but those in idiopathic fibrosis are similar to the bronchial carcinomas found in smokers $(63,64,68)$. Of special interest is the review by Mizushima \& Kobayashi (68). They collected 154 patients with lung cancer in idiopathic pulmonary fibrosis from the literature. They found that the following factors were typical for these cancers: there was a predominance among men, almost all occurred in smokers, the tumors were of the same type as among patients without pulmonary fibrosis (except for a higher incidence of small-cell carcinoma), and the tumors were peripheral and mainly situated in the lower lobes. In other words, the tumors were similar to those reported for patients with asbestosis.

It should be remembered, however, that "idiopathic" fibrosis is more than twice as common in persons with some type of occupational exposure to solvents or particles (69). At least some of the substances which presumably caused the fibrosis might in themselves be carcinogenic also. Indeed, asbestosis can be difficult to differentiate histologically from "idiopathic" interstitial fibrosis (apart from the presence of asbestos bodies) unless the exposure history is known.

In lungs with interstitial fibrosis, squamous-cell metaplasia and atypical cell proliferation can be seen far into the small bronchi $(63,70)$. Thus there are data indicating that the risk of lung cancer is increased in at least some types of diffuse fibrosis other than that caused by asbestos, and thus there is a plausible pathological mechanism 
to support this conclusion. These observations can be interpreted as supportive of the "asbestosis-cancer hypothesis".

\section{Correlation between fibrosis and lung cancer in animal studies}

In asbestos-exposed rats, the incidence of malignant tumors is related to the degree of fibrosis. However, as has been pointed out, the lung cancers in rats are histologically different from those in humans. The only conclusion one can draw from animal experiments is that both the fibrogenic and the carcinogenic effects are doserelated.

\section{Mutagenicity of asbestos}

Though the opposite has been claimed, asbestos is in fact a complete carcinogen $(59,71,72)$. This is evident for humans from the occurrence of mesotheliomas, for which asbestos seems to be the single causative agent.

\section{Epidemiologic studies in humans and excess lung cancer in asbestos exposure with and without asbestosis}

There is no doubt that patients with clinical and radiological asbestosis have a high risk of dying from lung cancer (table 1). At the highest exposure levels such as occurred in the early years of the industry, there may have been a lower cancer risk because the patients died from asbestosis before there was enough time to develop cancer $(41,82)$.

Several reports have indicated that the incidence of lung cancer is increased also for asbestos-exposed workers who lack radiological evidence of asbestosis. Some of these reports are listed in table 2.

\section{Radiological diagnosis of asbestosis}

The radiological diagnosis of asbestosis is not easy. The system developed by the International Labour Organisation (ILO) for evaluating pneumoconiosis, which has a 12-grade scale for parenchymal opacities, is used. As a general consensus, according to the ILO system, a degree of $1 / 0$ in a worker exposed to asbestos is accepted as manifest asbestosis, while $0 / 1$ is not. Unfortunately, the agreement between readers (or even the same reader at 2 different times) at this level is often not very good. The specificity and the sensitivity when compared with autopsy findings is also poor, and false negative and false positive results are very common $(87-89)$. A confounding factor is smoking, which can cause a significantly higher incidence of small irregular opacities in chest roentgenograms $(90,91)$. Since smoking is the main cause of lung cancer, there can be bias in that the risk for patients with radiological "asbestosis" might be overestimated.

\section{Dose-response for asbestosis}

Even if the correlation between exposure to asbestos and the occurrence of asbestosis is generally good, the lungs of some patients may be heavily burdened by asbestos without developing asbestosis (92).

\section{Correlation between lung cancer and asbestosis according to autopsy findings}

In many studies, the exposure to asbestos has been so large that most workers have some degree of asbestosis at autopsy. As proof of the "asbestosis-cancer hypothesis" some studies have been cited in which all patients with lung cancer also had asbestosis to some degree at autopsy. For instance, Kipen et al (1987) published 138 cases of lung cancer among asbestos insulation workers who all had asbestosis at autopsy; $18 \%$ of the asbestosis cases were not diagnosed from X-ray appearances (87).

In 1989 Sluis-Cremer reported autopsy findings from 339 amphibole asbestos miners (both crocidolite and amosite). Lung cancer correlated with heavy smoking, age, and asbestosis. The standardized mortality ratio for lung cancer did not show any excess for 302 exposed men without asbestosis, but it became progressively higher for those with asbestosis (93). The authors concluded that, in the absence of asbestosis at necropsy, a bronchial carcinoma in a man exposed to asbestos is unlikely to be due to asbestos. Since this study is one of the most cited in support of the "asbestosis-cancer hypothesis", it has to be realized that the study has some flaws. It is not an epidemiologic study. It was retrospective and based on the reports of different pathologists. We know nothing of the selection since only a portion of the workers came to

Table 1. Lung cancer in patients with asbestosis. (SMR $=$ standardized mortality ratio, $\mathrm{RR}=$ risk ratio)

\begin{tabular}{lrcccc}
\hline Author & N $\begin{array}{c}\text { Lung cancer } \\
\text { per cent } \\
\text { of deaths }\end{array}$ & $\begin{array}{c}\text { Ob- } \\
\text { served }\end{array}$ & $\begin{array}{r}\text { Ex- } \\
\text { pected }\end{array}$ & $\begin{array}{c}\text { SMR } \\
\text { or RR }\end{array}$ \\
\hline Couts et al, 1987 (73) & 155 & 39 &.. &.. & 7.4 \\
Berry, 1981 (74) & 283 & 39 &.. &.. &.. \\
Huuskonen, 1978 (75) & 202 & 32 &.. &.. & 9.0 \\
McMillan et al, 1978 (76) & 286 & 31.2 &.. &.. &.. \\
Buchanan, 1965 (77) & 97 & & 43 & 5.2 & 8.3 \\
Sluis-Cremer, 1991 (78) & 77 & & 9 & 2.1 & 4.3 \\
Hughes \& Weill, 1991(12) & 211 & & & & 2.3 \\
Wilkinson et al, 1995 (79) & 166 & & 9 & 3.9 & 2.3 \\
Hillerdal, 1994 (80) & & & & &
\end{tabular}


Table 2. Relative risk of lung cancer in asbestos-exposed cohorts without asbestosis (observed/expected values). ( $N=$ number of workers, $0=$ observed number of cases, $E=$ expected number of cases, $R R=$ risk ratio)

\begin{tabular}{|c|c|c|c|c|c|c|c|c|c|}
\hline \multirow[t]{2}{*}{ Author } & \multirow[t]{2}{*}{ Cohort } & \multicolumn{4}{|c|}{ No asbestosis } & \multicolumn{4}{|c|}{ Plaques only } \\
\hline & & $\mathbb{N}$ & 0 & $E$ & $\mathrm{RR}$ & $N$ & 0 & $E$ & $R R$ \\
\hline $\begin{array}{l}\text { Sluis-Cremer, } 1991 \\
\text { (78) }\end{array}$ & $\begin{array}{l}\text { Amphibole } \\
\text { miners }\end{array}$ &. &.. &.$\cdot$ &.. & 302 & 11 & 12.4 &.. \\
\hline $\begin{array}{l}\text { Edge, } 1976 \\
(82)\end{array}$ & $\begin{array}{l}\text { Shipyard } \\
\text { workers }\end{array}$ & ." &. & .. & ." & 235 & 13 & $5.4^{* * * *}$ & 2.4 \\
\hline $\begin{array}{l}\text { Fletcher, } 1972 \\
(83)\end{array}$ & $\begin{array}{l}\text { Shipyard } \\
\text { workers }\end{array}$ & 404 & 7 & 5.61 & 1.2 & 408 & 16 & $6.7^{* * *}$ & 2.4 \\
\hline $\begin{array}{l}\text { Loomis et al } 1989 \\
(84)\end{array}$ & $\begin{array}{l}\text { Normal } \\
\text { population }\end{array}$ & & & & & 59 &.$\cdot$ &.. & 3.0 \\
\hline $\begin{array}{l}\text { Sluis-Cremer, } 1991 \\
\text { (78) }\end{array}$ & $\begin{array}{l}\text { Normal } \\
\text { population }\end{array}$ & 738 & .. &.$\cdot$ & $1.56^{\star}$ &. &. &.. &.. \\
\hline $\begin{array}{l}\text { Lidelle McDonald, } 1980 \\
\text { (42) }\end{array}$ & $\begin{array}{l}\text { Chrysotile } \\
\text { miners } \\
(N=4559)\end{array}$ & .. &.. &.. & ." & $\begin{array}{l}286^{a} \\
190^{b}\end{array}$ & $\begin{array}{l}. . \\
. .\end{array}$ & $\begin{array}{l}. . \\
. .\end{array}$ & $\begin{array}{l}3.7^{a} \\
2.8^{b}\end{array}$ \\
\hline $\begin{array}{l}\text { Hillerdal, } 1994 \\
(80)\end{array}$ & $\begin{array}{l}\text { Plaque } \\
\text { carriers }\end{array}$ &.. &.. &.. &.. & 1430 & 41 & $28.2^{*}$ & 1.4 \\
\hline $\begin{array}{l}\text { Sandén \& Järnholm, } 1987 \\
\text { (85) }\end{array}$ & $\begin{array}{l}\text { Shipyard } \\
\text { workers }\end{array}$ & 1095 & 6 & 4.3 &. & 626 & 3 & 2.9 &. \\
\hline $\begin{array}{l}\text { Hughes \& Weill, } 1991 \\
\text { (12) } \\
\text { workers }\end{array}$ & $\begin{array}{l}\text { Asbestos } \\
\text { cement }\end{array}$ &..$c$ & 10 & 8.1 & 1.2 & 62 & 2 & 1.5 & 1.3 \\
\hline $\begin{array}{l}\text { Loomis et al } 1988 \\
(86)\end{array}$ & $\begin{array}{l}\text { Plaque } \\
\text { carriers }\end{array}$ &. &. & .. &.. & $83^{e}$ & 11 & 3.3 & 3.3 \\
\hline
\end{tabular}

a Uncalcified, calculated from article and might contain some with asbestosis (not clear from article).

- Calcified, calculated from article and might contain some with asbestosis (not clear from article).

c Only workers with $\leq 20$ years of latency from first exposure.

d Estimated value from text.

- A few of these patients probably had asbestosis, not clear from text

${ }^{*} P<0.05 ;{ }^{* *} P<0.01 ;{ }^{* * *} P<0.005 ;{ }^{* * *} P<0.001$.

autopsy, and there was also bias, because the pathologists knew at an early stage whether the patient had cancer or not.

However, most autopsy findings do support the "asbestosis-cancer" theory. There are exceptions however. For instance, there is 1 study in which more than half the patients exposed to asbestos had lung cancer but no asbestosis at autopsy (88).

\section{Correlation between lung cancer and asbestosis according to radiological findings}

Some epidemiologic studies have been made concerning radiological findings and subsequent development of lung cancer. The study of Hughes \& Weill (12) is of special interest since it has been cited by many reviewers and by the authors themselves as support for the "asbestosis-cancer hypothesis" and "proof" that cancer is no more common than expected in asbestos-exposed persons without asbestosis. As seen from table 2, the relative risk for lung cancer in men without asbestosis in this group is in fact 1.2 (ie, a 20\% increase), and, though this is of course not statistically significant, it is statistical speciousness to claim that a lack of excess tumors has been proved in this study. In addition, the authors collected data from 2 factories. In 1 of the 2 crocidolite was used to some extent, and this factor was the only 1 of the 2 factories in which there was an excess of lung cancer
(94). Thus crocidolite seems to be the main risk factor rather than the occurrence of asbestosis.

Some studies on asbestos-related lung cancer have also been published in which some of the patients did not have any fibrosis (76, 95-97). Thus, in many instances, the risk of asbestosis does not parallel the risk of lung cancer (25).

\section{Asbestos fibers or bodies and lung cancer}

In several studies, the occurrence of asbestos fibers or bodies or both in the lungs of lung cancer patients either in rejected lung tissue or at autopsy - have been compared with findings from referents. Some such studies are summarized in table 3 . The fiber levels are increased in patients with lung cancer even if there is no asbestosis present. For example, in the Karjalainen study (98), only 2 of the 113 cancers had radiological asbestosis, and another 7 had slight histological fibrosis.

\section{Pleural plaques and risk of lung cancer}

In most investigations, pleural plaques are the most common radiological finding in persons exposed to asbestos. 
Table 3. Asbestos fibers and bodies and lung cancer.

\begin{tabular}{|c|c|c|c|c|}
\hline Author & Material & Cases $(\mathrm{N})$ & Asbestosis & Results \\
\hline Karjalainen et al, 1993 (98) & Operated & 113 & 9 & $\begin{array}{l}\text { OR } 2.8 \geq 5 \times 10^{6} / \mathrm{g} \text { per gram } \\
\text { OR } 1.5 \geq 1 \times 10^{6} / \mathrm{g} \text { per gram }\end{array}$ \\
\hline Martischnig, 1977 (47) & Autopsy & 30 & - & $\begin{array}{l}\text { Significant higher levels of ferruginous bodies } \\
\text { in patients with lung cancer }\end{array}$ \\
\hline Smith, 1968 (99) & Autopsy & 107 & - & More asbestos bodies in patients with lung cancer \\
\hline Kishimoto, $1992(100)$ & Autopsy & 92 & .. & More asbestos bodies in patients with lung cancer $(P<0.01)$ \\
\hline Hiraoka et al, 1990 (101) & $\begin{array}{l}\text { Autopsy } \\
\text { Operated }\end{array}$ & $\begin{array}{l}337 \\
139\end{array}$ & 10 & $\begin{array}{l}\text { More asbestos bodies in patients with lung cancer; high counts } P<0.01 \text {; } \\
\text { low counts } P<0.05\end{array}$ \\
\hline
\end{tabular}

They are in themselves harmless and can be regarded as an objective sign of previous asbestos inhalation. If there is a linear dose-response relationship between lung cancer and asbestos, the logical consequence would be that persons with plaques should have an increased incidence of bronchial carcinoma. On the other hand, if the "asbestosis-cancer hypothesis" is correct, there should be no increased risk unless the plaques are combined with asbestosis.

\section{Radiological diagnosis of plaques}

The ILO system for diagnosing plaques has a low specificity and sensitivity. At autopsy less than half of the plaques seen radiologically actually exist, but despite this fact more than twice as many remain undiagnosed (102-105). Thus, to reach an acceptable level of specificity, strict criteria are necessary $(102,106)$. Unfortunately, the sensitivity will then be low - and the majority of the genuine plaques will never be diagnosed (102105). It is difficult to evaluate any study using unspecified or ILO criteria.

\section{Degree of exposure and plaques}

In the general population in a society in which there are no "endemic plaques", $80-90 \%$ of strictly defined pleural plaques discovered in chest roentgenograms are due to occupational exposure to asbestos (80). A good correlation between pleural plaques and asbestos fibers or bodies in the lung has been shown by many researchers $(22,99,107-115)$. Asbestos bodies in sputum are also correlated with pleural and parenchymal changes (116). There is also a fair correlation between the number of asbestos fibers in the lung parenchyma and the size of the plaques $(113,115,117)$. This correlation supports the finding that the average or cumulative dust exposure is a significant determinant for the progression of pleural abnormalities (118-120). Since definite criteria would single out those with the largest plaques, they would tend to select those with the heaviest exposure.

However, even if the mean of asbestos fibers or bodies in persons with plaques is higher than in the normal population, there is a fairly large variation, and some persons with plaques will have values that are little or no different from those of the general population $(111,114)$.

Ten percent of the persons with nonmalignant asbestos-related pleural lesions without signs of parenchymal fibrosis will develop radiological and clinical evidence of it in a 10 -year period $(76,80,121)$. Slightly restrictive lung function has been reported for groups with asbestos-induced pleural lesions; the principal determinant of this restrictive lung function is probably parenchymal inflammation or fibrosis (122). In careful pathological investigations, small lesions in the bronchioles and surrounding parenchyma can be found in most patients with pleural plaques $(123,124)$. Thus the followers of the "asbestosis-cancer hypothesis" might accept the fact that persons with plaques do have an increased risk of cancer - and attribute this to subradiological asbestosis, which may be present in some these patients.

\section{Plaques and risk of cancer}

Whether patients with plaques have an increased risk of bronchial carcinoma or not has been hotly debated. A strong opinion argues that there is no excess cancer for carriers of simple plaques compared with those without $(13,125,126)$ or that, if there is such an excess, it is explicable by more prevalent smoking among patients with plaques (127). However, in some studies, the incidence of bronchial carcinoma has been reported to be increased for those with plaques (table 3 ).

Many studies indicate that plaques are more than twice as common in chest $X$ rays of lung cancer patients as in $X$ rays of the general population (128-132). The same holds true for plaques at autopsy or determined during operation (table 4), but these studies could be biased by the investigator's knowledge of a tumor.

There are also reports in which no excess has been found in patients with plaques. Harper et al compared 13 patients with bronchial carcinoma from 1500 workers exposed to asbestos and found no trend toward an association of pleural plaques with subsequent malignancy (133).

It seems that even low levels of exposure to asbestos (such as the environmental plaques in Finland) can result in plaques. These plaques do not seem to indicate a 
Table 4. Pleural plaques and cancer at autopsy or operation. (RR = risk ratio)

\begin{tabular}{|c|c|c|c|c|c|}
\hline Author & Material & $\begin{array}{l}\text { Type of } \\
\text { referents }\end{array}$ & $\begin{array}{l}\text { Ob- } \\
\text { served }\end{array}$ & $\begin{array}{c}\text { Ex- } \\
\text { pected }\end{array}$ & $\mathrm{RR}$ \\
\hline $\begin{array}{l}\text { Wain, et al } \\
1984 \\
(103)\end{array}$ & $\begin{array}{l}409 \\
\text { autopsies } \\
\text { the group }\end{array}$ & $\begin{array}{l}\text { Compared } \\
\text { within }\end{array}$ & 4 & 3.4 & 1.2 \\
\hline $\begin{array}{l}\text { Smith, } 1968 \\
(99)\end{array}$ & $\begin{array}{l}109 \\
\text { autopsies }\end{array}$ & $\begin{array}{l}\text { Age/gender } \\
\text { matched }\end{array}$ & 27 & 16 & 1.7 \\
\hline $\begin{array}{l}\text { Mollo, et al } \\
1985 \\
(117)\end{array}$ & $\begin{array}{l}1019 \\
\text { autopsies } \\
\text { the group }\end{array}$ & $\begin{array}{l}\text { Compared } \\
\text { within }\end{array}$ & & & 1.9 \\
\hline $\begin{array}{l}\text { Toty, et al } \\
1976 \\
(132)\end{array}$ & $\begin{array}{l}125 \\
\text { operated } \\
\text { cancer }\end{array}$ & $\begin{array}{l}\text { Operated } \\
\text { without }\end{array}$ & 30 & 10.4 & 2.9 \\
\hline
\end{tabular}

measurably increased risk of cancer (134). This study also showed that there was no increased risk in persons with fibrosis only - but fibrosis in combination with plaques gave a relative risk of 2.8! In a later Finnish study, a rough estimate of the relative lung cancer risk for patients with these mainly environmental plaques in comparison with that of the general population gave the figure of $1.1(136)$ - which is such a small risk that unrealistically large population studies would be necessary to prove it statistically (137).

\section{Lobar distribution and histological type of lung cancer in patients with asbestos exposure}

Generally, lung tumors are more common in the upper lobes than in the lower ones. In asbestos workers the reverse is true $(31,81,95,138)$. This reversal is seen also in asbestos-exposed cohorts without pulmonary fibrosis $(50,95,139)$. In 1 of these studies, in patients with more than 2 million fibers/g of dry weight of lung tissue, 59\% of the cancers were situated in the lower lobes, while, in those with less, only $29 \%$ had this distribution (138).

Adenocarcinomas are reported to be relatively more common among persons exposed to asbestos than among unexposed persons $(95,75,128,139-141)$. There is, however, no consensus on this report (137), and the incidence of all the main types of bronchial carcinoma is in fact increased $(96,138,141,143-146)$. There are indications that with heavier exposure, and thus in patients with asbestosis, relatively more adenocarcinomas are seen $(22,31,139,142,145)$. At lower exposure levels, squamous-cell carcinomas seem to be more common $(47,80,143,146)$. This phenomenon might reflect the relative importance of smoking versus asbestos; at a lower exposure level to asbestos, the "tobacco effect" predominates, creating mainly squamous carcinomas.

\section{Relative and "attributable" risk of asbestos in lung cancer patients}

Various reports have tried to outline the importance of asbestos as a cocarcinogen in lung cancer. Case-referent or similar studies of patients with lung cancer reported an attributable risk of $6 \%$ to $23 \%$ for asbestos (table 5 ). Occupations with exposure to asbestos are overrepresented among clinical cases of lung cancer $(129,130$, 151).

The actual occurrence of asbestosis among clinical cases of lung cancer is much lower than the $6 \%$ to $23 \%$, when asbestos played a role according to the epidemiologists. Of special interest is the study by Wilkinson et al (79), in which lung cancer cases were compared with referents, not only regarding occupational exposure and

Table 5. Percentage of "attributable risk" of asbestos in lung cancer. (RR = risk ratio)

\begin{tabular}{|c|c|c|c|c|c|c|}
\hline Author & Cohort & $\begin{array}{c}\text { Cases } \\
(\mathrm{N})\end{array}$ & $\begin{array}{c}\text { Asbes- } \\
\text { tosis }\end{array}$ & Referents & $\mathrm{RR}$ & $\begin{array}{c}\text { Attributable risk } \\
(\%)\end{array}$ \\
\hline De Vos \& Irvine et al, 1993 (146) & Men in west Scotland & .. & ." & - & - & 6 \\
\hline Karjalainen et al, 1994 (115) & Surgery & 65 & $5(1+4)$ & 297 & - & 19 \\
\hline Imbernon et al, 1995 (145) & Workers (gas, electricity) & 310 &.. & 1240 & 1.4 & .. \\
\hline Kjuus et al, $1986(143)$ & Surgery & 176 & $?$ & 176 & 3.0 & 23 \\
\hline Vena et al, 1985 (142) & Patients & 1002 & .. & 1119 & $\begin{array}{l}1.7^{\mathrm{a}} \\
2.9^{\mathrm{b} * \star}\end{array}$ & $\cdot$. \\
\hline $\begin{array}{l}\text { Stayner et al, } 1996(46) \\
\text { Wilkinson et al, } 1995(79)\end{array}$ & $\begin{array}{l}\text { Surgery } \\
\text { Patients }\end{array}$ & $\begin{array}{l}201 \\
271\end{array}$ & - & $\begin{array}{l}201 \\
678\end{array}$ & $\begin{array}{l}2.35^{* * \star} \\
1.7^{*}\end{array}$ & $\begin{array}{l}. . \\
. .\end{array}$ \\
\hline Blot et al, $1978(147)$ & General population & 535 & $?$ & 659 & $1.6^{* * *}$ & .. \\
\hline Järvholm et al, 1993 (148) & Göteborg & 147 & $?$ & $\begin{array}{l}111 \\
109\end{array}$ & $1.6-1.8$ & 16 \\
\hline Bovenzi et al, 1992 (149) & Trieste & 756 & $?$ & 756 & 2.0 & 20 \\
\hline
\end{tabular}

a Exposed $<20$ years.

b Exposed $>20$ years.

${ }^{*} P<0.05 ;{ }^{* *} P<0.01 ; * * * P<0.001$. 
smoking habits, but also regarding the occurrence of parenchymal small lesions according to ILO. As seen from the tables, the relative risk for lung cancer for patients with changes compatible with asbestosis ( $1 / 0$ or more) was 2.03 , and for those without asbestosis it was 1.56.

All the studies cited here and seen in the table agree fairly well. One must therefore conclude that lung cancer risk is increased also in patients without asbestosis.

\section{Mechanism of asbestos-related lung cancer}

It has been claimed that fibrosis in the lung parenchyma is unlikely to cause cancer in the large bronchi, where a large part of asbestos-related cancers are seen $(58,152$, 153). In tracheal organ cultures, necrosis and desquamation of surface cells accompanied by basal cell hyperplasia can be seen after 1 week (154), and this occurrence is presumably independent of any accompanying parenchymal changes. These changes presumably cause an increase in the susceptibility of epithelial cells of the bronchi to be transformed by environmental carcinogens (31). Fibrosis of the lungs and cancer of the bronchi can thus be seen as end points of 2 unknown mechanisms that may work independently (153).

\section{Concluding remarks}

There is an increasing body of evidence which indicates that asbestos at low exposure levels produces a slight increase in the relative risk of lung cancer. The relative risk of cancer in asbestosis patients is higher, but it is unclear whether this higher risk is attributable entirely to higher fiber burden within lung tissue (a dose-response effect) or whether there is also an adjuvant effect of fibrosis by way of cytokine production, over and above the dose effect.

This conclusion is not a purely academic question but has important practical consequences in 2 different areas. One is in the legal world and the other is in the world of industrial hygienists. The legal consequences have an important bearing for many persons. Accepting a nothreshold hypothesis for lung cancer would open the field for a large number of patients with low-grade exposure to claim compensation for lung cancers caused by asbestos exposure, even when the principal cause of the tumor is smoking. However, science should try to find the facts independent of how the law might be affected by these findings. In other words, law should follow science, not the other way around. The legal world has to come to terms with whether - and if so, how much - a small increased risk, such as an increased risk of $10 \%$ or $20 \%$, should be compensated. Proposals have been made (33).

The more important fact is that even if an increased risk of $10 \%$ or $20 \%$ is not very important for a person, it will result in a large number of bronchial carcinomas in the general population where smoking, unfortunately, is far from eliminated. Given this fact, society cannot conclude from the present data that lung cancer risk is increased only when exposure is heavy enough to cause asbestosis. Anyone claiming such an unproved hypothesis shoulders a heavy responsibility. All exposure to asbestos must be minimized, and if asbestos is to be used, stringent precautions must be taken.

\section{References}

1. Gloyne SR. Two cases of squamous carcinoma of the lung occurring in asbestosis. Tubercle 1935;17:5-10.

2. Nordmann M. Der Berufskrebs der Asbestarbeiter. Z Krebsforsch 1938;47:288-302.

3. Lynch KM, Cannon WM. Asbestosis: analysis of forty necropsied cases. Dis Chest 1948;14:874-89.

4. Doll R. Mortality from lung cancer in asbestos workers. Br J Ind Med 1955;12:81-6.

5. Enterline PE. Changing attitudes and opinions regarding asbestos and cancer 1934 - 1965. Am J Ind Med 1991;20:685700 .

6. Knox JF, Holmes S, Doll R, Hill ID. Mortality from lung cancer and other causes among workers in an asbestos textile factory. Br J Ind Med 1968;25:293 - 303.

7. Enterline PE, Henderson V. Type of asbestos and respiratory cancer in the asbestos industry. Arch Environ Health 1973;27: 312-7.

8. Parkes WR. Review article: asbestos-related disorders. Br J Dis Chest 1973;67:261-300.

9. Enterline PE. Estimating health risks in studies of the health effects of asbestos. Am Rev Respir Dis 1976;113:175—80.

10. Sluis-Cremer GK. The relationship between asbestosis and bronchial cancer. Chest 1980;78 suppl:380-1.

11. Browne $\mathrm{K}$. Is asbestos or asbestosis the cause of increased risk of lung cancer in asbestos workers? Br J Ind Med 1986; 43:145-9.

12. Hughes JM, Weill H. Asbestos as a precursor of asbestos related lung cancer: results of a prospective mortality study. $\mathrm{Br} J$ Ind Med 1991;48:229-33.

13. Morgan WKC. The pneumoconioses. Curr Opin Pulm Med 1995;1:82-8.

14. Wright GW. Asbestos and health in 1969. Am Rev Respir Dis 1969;100:467-78.

15. Hammond EC, Selikoff IJ. The effects of air pollution: epidemiological evidence. In: Shapiro HA, editor. Pneumoconiosis: Proceedings of the International Conference; 1969; Johannesburg. Cape Town: Oxford University Press, 1970: 368-73.

16. Wagner JC, Gilson JC, Berry G and Timbrell V. Epidemiology of asbestos cancers. Br Med Bull 1971;27:71 - 6 .

17. Newhouse ML, Berry G, Wagner JC, Turok ME. A study of the mortality of female asbestos workers. Br J Ind Med 1972; 
$29: 134-41$.

18. Becklake MR, Asbestos-related diseases of the lung and other organs: their epidemiology and implications for clinical practice. Am Rev Respir Dis 1976;114:187—227.

19. Turiaf J, Battesti JP. Le pouvoir cancérigène de l'amiante sur les voies aériennes. Rev Fr Mal Respir 1976;suppl 2 au Tome $4: 39-50$.

20. Nicholson WJ. Case study I: asbestos - the TLV approach. Ann NY Acad Sci 1976;271:152-69.

21. Saracci R. Asbestos and lung cancer: an analysis of the epidemiological evidence on the asbestos-smoking interaction. Int J Cancer 1977;20:323-31.

22. Whitwell F, Scott J, Grimshaw M. Relationship between occupations and asbestos-fibre content of the lungs in patients with pleural mesothelioma, lung cancer, and other diseases. Thorax 1977;32:377-86.

23. Peto J. The hygiene standard for chrysotile asbestos. Lancet 1978;1:484-9.

24. Preger L. Lung cancer. In: Preger L, editor. Asbestos-related disease. New York (NY): Grune and Stratton, 1978:174 204.

25. Henderson VL, Enterline PE. Asbestos exposure: factors associated with excess cancer and respiratory disease mortality. Ann NY Acad Sci 1979;330:117-26.

26. Lemen RA, Dement JM, Wagoner JK. Epidemiology of asbestos-related diseases. Environ Health Perspect 1980;34:1 11

27. McDonald JC. Asbestos and lung cancer: has the case been proven? Chest 1980;78 suppl:374S-6S.

28. Newhouse M. Epidemiology of asbestos-related tumors. Semin Oncol 1981;8;250-7.

29. Casey KR, Rom WN, Moatamed F. Asbestos-related diseases. Clin Chest Med 1981;2:179_-202.

30. Becklake MR, Asbestos-related diseases of the lungs and pleura: current clinical issues. Am Rev Respir Dis 1982;126: $187-94$.

31. Craighead JE, Mossman BT. The pathogenesis of asbestosassociated diseases. N Engl J Med 1982;306:1446 - 55 .

32. Walker AM, Loughlin JE, Friedlander ER, Rothman KJ, Dreyer NA. Projections of asbestos-related disease 1980 2009. J Occup med 1983;25:409-25.

33. Chase GR, Kotin P, Crump K, Mitchell RS. Evaluation for compensation of asbestos-exposed individuals, II: apportionment of risk for lung cancer and mesothelioma. J Occup Med 1985;27:189_-98.

34. Doll R, Peto J. Effects on health of exposure to asbestos. London: Her Majesty's Stationery Office, 1985

35. Liddell FDK, Hanley JA. Relations between asbestos exposure and lung cancer SMRs in occupational cohort studies. $\mathrm{Br}$ $\mathrm{J}$ Ind Med 1985;42:389-96.

36. Seidman H, Selikoff IJ, Gelb SK. Mortality experience of amosite asbestos factory workers: dose-response relationships 5 and 40 years after onset of short-term exposure. Am J Ind Med 1986;10:479 $\quad 514$.

37. World Health Organization (WHO). Asbestos and other natural mineral fibers. Geneva: WHO, 1986. Environment health criteria.

38. Enterline PE. Asbestos and cancer: a cohort followed up to death. Br J Ind Med 1987;44:396-401.

39. Dunn MM. Asbestos and the lung. Chest 1989;95:1304-8.

40. Dement JM, Brown DP, Okun A. Follow-up study of chrysotile asbestos textile workers: cohort mortality and casecontrol analyses. Am J Ind Med 1994;26:431-47.

41. Nicholson WJ. Cancer following occupational exposure to asbestos and to vinyl chloride. Cancer 1977;39:1792-1801.

42. Liddell FDK, McDonald JC. Radiological findings as predictors of mortality in Quebec asbestos workers. Br $\int$ Ind Med $1980 ; 37: 257-67$.

43. Selikoff IJ, Seidman H, Hammond EC. Mortality effects of cigarette smoking among amosite asbestos factory workers. JNCI 1980;65:507-13.

44. Seidman H, Selikoff IJ, Hammond EC. Short-term asbestos exposure and long-term observation. Ann NY Acad Sci 1979; $330: 61-89$

45. Hughes JM, Weill H, Hammad YY. Mortality of workers employed in two asbestos cement manufacturing plants. Br J Ind Med 1987;44:161 - 74.

46. Stayner LT, Dankovic DA, Lemen RA. Occupational exposure to chrysotile asbestos and cancer risk: a review of the amphibole hypothesis. Am J Public Health 1996;86:17986.

47. Martischnig KM, Newell DJ, Barnsley WC, Cowan WK, Feimmann EL, Oliver E. Unsuspected exposure to asbestos and bronchogenic carcinoma. Br Med J 1977;1:746-9.

48. Warnock ML, Churg AM. Association of asbestos and bronchogenic carcinoma in a population with low asbestos exposure. Cancer 1975;35:1236-42.

49. Finkelstein MM. Mortality among employees of an Ontario asbestos-cement factory. Am Rev Respir Dis 1984;129:754 61.

50. Anttila S, Karjalainen A, Tiakina-Aho O, Kyrönen P, Vainio $\mathrm{H}$. Lung cancer in the lower lobe is associated with pulmonary asbestos fiber count and fiber size. Environ Health Perspect 1993;101:166-170.

51. Karjalainen A, Karhunen P, Lalu K, Penttilä A, Vanhala E, Kyyrönen $P$, et al. Pleural plaques and exposure to mineral fibers in a male and the risk of lung cancer in a male urban necropsy population. Occup Environ Med 1994;51:456-60.

52. Gardner MJ, Winter PD, Pannett B, Powell CA. Follow up study of workers manufacturing chrysotile asbestos cement products. Br J Ind Med 1986;43:726-32.

53. Ohlson CG, Hogstedt C. Lung cancer among asbestos cement workers: a Swedish cohort study and a review. $\mathrm{Br}$ J Ind Med 1985;42:397-402.

54. Thomas HF, Benjamin IT, Elwood PC, Sweetnam PM. Further follow-up study of workers from an asbestos cement factory. Br J Ind Med 1982;39:273-6.

55 . Weiss W. Mortality of a cohort exposed to chrysotile asbestos. J Occup Med 1977;19:737-40

56. Dement JM. Carcinogenicity of chrysotile asbestos: evidence from cohort studies. Ann NY Acad Sci 1991;643:15-23.

57. Tubiana $\mathrm{M}$. The carcinogenic effect of exposure to low doses of carcinogens [editorial]. Br J Ind Med 1992;49;601-5.

58. Roggli VL, Hammar SP, Pratt PC, Maddox JC, Legier J, Mark EJ, et al. Does asbestos or asbestosis cause carcinoma of the lung? [commentary]. Am J Ind Med 1994;26:835-8.

59. Meurman LO, Kiviluoto R, Hakama M. Combined effect of asbestos exposure and tobacco smoking on Finnish anthophyllite miners and millers. Ann NY Acad Sci 1979;330: $491-5$.

60. Vainio H, Boffetta P. Mechanisms of the combined effect of asbestos and smoking in the etiology of lung cancer [review]. Scand J Work Environ Health 1994;20:235 42.

61. Siemiatycki J, Wacholder S, Dewar R, Cardis E, Greenwood $C$, Richardson L. Degree of confounding bias related to smoking, ethnic group, and socioeconomic status in estimates of the associations between occupation and cancer. $J$ Occup Med 1988:30:617-25. 
62. Talbott $\mathbf{J H}$, Barrocas $\mathbf{M}$. Carcinoma of the lung in systemic sclerosis: a tabular review of the literature and a detailed report of the roentgenographic changes in two cases. Semin Arthritis Rheum 1980;9:191--217.

63. Turner-Warwick M, Lebowitz M, Burrows B, Johnson A. Cryptogenic fibrosing alveolitis and lung cancer. Thorax 1980;35:496-9.

64. Nagai A, Chiyotani A, Nakadate T, Konno K. Lung cancer in patients with idiopathic pulmonary fibrosis. Tohuku J Exp Med 1992;167:231-7.

65. Goldsmith DF. Silica exposure and pulmonary cancer. In: Samet JM, editor. Epidemiology of lung cancer. New York (NY): Marcel Dekker, 1994:245—98.

66. Goldsmith DF, Wagner GR, Saffiotti U, Rabovsky J, Leigh J Special issue: second international symposium on silica, silicosis, and cancer. Scand J Work Environ Health 1995;21 suppl 2.

67. Weill H, McDonald JC. Exposure to crystalline silica and risk of lung cancer: the epidemiological evidence. Thorax 1996;51:97-102.

68. Mizuzhma Y, Kobayashi M. Clinical characteristics of synchronous multiple lung cancer associated with idiopathic pulmonary fibrosis: a review of Japanese cases. Chest 1995;108: $1272-77$.

69. Iwai K, Mori T, Yamada N, Yamaguchi M, Hosoda Y. Idiopathic pulmonary fibrosis: epidemiologic approaches to occupational exposure. Am J Respir Crit Care Med 1994;150: $670-5$.

70. Meyer EC, Liebow AA. Relationship of interstitial pneumonia, honeycombing, and atypical epithelial proliferation to cancer of the lung. Cancer 1965;18:322-51.

71. Brody AR. Asbestos-induced lung disease. Environ Health Perspect 1993;100:21-30.

72. Rom WR, Travis WD, Brody AR. Cellular and molecular basis of the asbestos-related diseases. Am Rey Respir Dis $1991 ; 143: 408-22$.

73. Coutts II, Gilson JC, Kerr IH, Parkes WR, Turner-Warwick M. Mortality in cases of asbestosis diagnosed by a pneumoconiosis medical panel. Thorax 1987;42:111-6

74. Berry G. Mortality of workers certified by pneumoconiosis medical panels as having asbestosis. $\mathrm{Br} \mathrm{J}$ Ind Med $1981 ; 38: 130-7$.

75. Huuskonen MS. Clinical features, mortality and survival of patients with asbestosis. Scand J Work Environ Health 1978; $4: 265-74$.

76. McMillan GHG, Sheers G, Pethybidge R. A radiological follow-up study of the effect of asbestos in dockyard workers at Devonport. J R Nav Med Serv 1978;64:88- 104.

77. Buchanan WD. Asbestosis and primary intrathoracic neoplasms. Ann NY Acad Sci 1965;132:507-18.

78. Sluis-Cremer GK. Asbestos disease at low exposures after long time residence. Ann NY Acad Sci 1991;643:182-93.

79. Wilkinson P, Hansell DM, Janssens J, Rubens M, Rudd RM, Newman-Taylor A, et al. Is lung cancer associated with asbestos exposure when there are no small opacities on the chest radiographs? Lancet 1995;345:1074-8.

80. Hillerdal G. Pleural plaques and risk for bronchial carcinoma and mesothelioma: a prospective study. Chest 1994;105: $144-50$.

81. Jacob G, Anspach M. Pulmonary neoplasia among Dresden asbestos workers. Ann NY Acad Sci 1965;132:536-48.

82. Edge JR. Asbestos-related disease in Barrow-in-Furness. Environ Res 1976;11:244-7.

83. Fletcher DE. A mortality study of ship yard workers with pleural plaques. Br J Ind Med 1972;29:142-5.

84. Loomis DP, Collman GW, Rogan WJ. Relationship of mortality, occupation, and pulmonary diffusing capacity to pleural thickening in the first national health and nutrition examination survey. Am J Ind Med 1989;16:477-84.

85. Sandén $\AA$, Järvholm B. Cancer morbidity in Swedish shipyard workers 1978-1983. Int Arch Occup Environ Health $1987 ; 59: 455-62$

86. Navratil M, Moravkova K, Gafronova M, Hruska F. The fate of people with pleural hyalinosis (plaques): relationship to direct and indirect asbestos exposure. Czech Med 1988;11: $146-56$.

87. Kipen HM, Lilis R, Suzuki Y, Valciukas JA, Selikoff IJ. Pulmonary fibrosis in asbestos insulation workers with lung cancer: a radiological and histopathological evaluation. Br J Ind Med 1987:44:96-100.

88. Giesen T. The validity of radiological and histological findings in former asbestos workers with lung cancer. In: Proceedings of the VII International Pneumoconiosis Conference: part I. Pittsburg (PA): United States Department of Health and Human Services, 1988:520-4.

89. Sluis-Cremer GK, Hessel PA, Hnizdo E. Factors influencing the reading of small irregular opacities in a radiological survey of asbestos miners in South Africa. Arch Environ Health 1989;44:237-43.

90. Weiss W. State of the art: cigarette smoke, asbestos, and small irregular opacities. Am Rev Respir Dis 1984;130:293301.

91. Lilis R, Selikoff IJ, Lerman Y, Seidman H, Gelb K. Asbestosis: interstitial pulmonary fibrosis and pleural fibrosis in a cohort of asbestos insulation workers: influence of cigarette smoking. Am J Ind Med 1986;10:459-70.

92. Henderson DW, Roggli VL, Shilkin KB, Hammar S, Leigh J. Is asbestosis an obligate precursor for asbestos-induced lung cancer? Fibre burden and the changing balance of evidence: a preliminary discussion document. In: Peters GA, Peters BJ, editors. Sourcebook on asbestos diseases; vol II. Charlottesville (NC): Michie Company, 1995:97--170.

93. Sluis-Cremer GK, Bezuidenhout BN. Relation between asbestosis and bronchial cancer in amphibole miners. Br J Ind Med 1989;46:537-40.

94. Hughes JM, Weill H, Hammad YY. Mortality of workers employed in two asbestos cement manufacturing plants. Br J Ind Med 1987;44:161-74.

95. Hourihane DOB, McCaughey WTE. Pathological aspects of asbestosis. Postgrad Med J 1966;42:613-22.

96. Newhouse ML, Berry G, Wagner JC. Mortality of factory workers in east London 1933-80. Br J Ind Med 1985;42:411.

97. Wagner JC, Pooley FD, Berry G, Seal RME, Munday DE, Morgan J, et al. A pathological and mineralogical study of asbestos-related deaths in the United Kingdom in 1977. Ann Occup Hyg 1982;26:423-31.

98. Karjalainen A, Anttila S, Heikkilä L, Karhunen P, Vainio H. Asbestos exposure among Finnish lung cancer patients: occupational history and fiber concentration in tissue. Am J Ind Med 1993;23:461-71.

99. Smith PG. Pulmonary asbestos bodies, pleural hyaline plaques and neoplasia in man. In: Proceedings of the conference on biological effects of asbestos; 1968; Dresden. Berlin: Deutsche Zentralinstitut für Arbeitsmedizin, 1968:277-9.

100. Kishimoto T. Cancer due to asbestos. Chest 1992;101:58 63.

101. Hiraoka K, Horie A, Kido M. Study of asbestos bodies in 
Japanese urban patients. Am J Ind Med 1990;18:547-54.

102. Hillerdal G, Lindgren A. Pleural plaques: correlation of autopsy findings to radiographic findings and occupational history. Eur J Respir Dis 1980;61:315 - 9.

103. Wain SL, Roggli VL, Foster WJ. Parietal pleural plaques, asbestos bodies, and neoplasia: a clinical, pathologic, and roentgenographic correlation of 25 consecutive cases. Chest 1984;86:707-13.

104. Svenes KB, Borgersen A, Haaversen O, Holten K. Parietal pleural plaques: a comparison between autopsy and X-ray findings. Eur J Respir Dis 1986;69:10-5.

105. Frumkin H, Pransky G, Cosmatos I. Radiologic detection of pleural thickening. Am Rev Respir Dis 1990;142:1325-30.

106. Greene R, Boggis C, Jantsch H. Asbestos-related pleural thickening: effect of threshold criteria on interpretation. Radiology 1984;152:569-73.

107. Macpherson P, Davidson JK. Correlation between lung asbestos count at necropsy and radiological appearances. $\mathrm{Br}$ Med J 1969;1:355-7.

108. Pratt PC, Brody AR. Asbestos content of lung tissue in asbestos associated disease: a study of 110 cases. $\mathrm{Br} \mathbf{J}$ Ind Med 1986;43:18-28.

109. Gylseth B, Mowé G, Skaug V, Wannag A. Inorganic fibers in lung tissue from patients with pleural plaques or malignant mesothelioma. Scand J Work Environ Health 1981;7:10913 .

110. Warnock ML, Prescott BT, Kuwahara TJ. Numbers and types of asbestos fibers in subjects with pleural plaques. Am J Pathol 1982;109:37-46.

111. Roggli VL, Pratt PC, Brody AR. Asbestos content of lung tissue in asbestos associated diseases: a study of 110 cases. Br J Ind Med 1986;43:18 - 28.

112. Mollo F, Andrion A, Bertasso L, Colombo A. Placche pleuriche ialine ed esposizione all'asbesto [Pleural plaques and asbestos exposure]. Pathologica 1980;72:55- 65 .

113. Kishimoto T, Ono T, Okada K, Ito H. Relationship between number of asbestos bodies in autopsy lung and pleural plaques on chest X-ray film. Chest 1989;95:549-52.

114. Ren H, Lee DR, Hruban RH, Kuhlman JE, Fishman EK, Wheeler PS, et al. Pleural plaques do not predict asbestosis: high-resolution computed tomography and pathology study. Mod Pathol 1991;4:201-9.

115. Karjalainen A, Anttila S, Vanhala E, Vainio H. Asbestos exposure and the risk of lung cancer in a general urban population. Scand J Work Environ Health 1994;20:243-50.

116. McLarthy JW, Greenberg DS, Hurst GA, Spivey CG, Seitzman LH, Rieger RL, et al. The clinical significance of ferruginous bodies in sputa. J Occup Med 1980;22:92-6.

117. Mollo F, Andrion A, Bellis D, Bertoldo E, Colombo E. Screening of autopsy populations for previous occupational exposure to asbestos. Arch Environ Health 1987;42:44-50.

118. Sheers G, Templeton AR. Effects of asbestos in dock yard workers. Br Med J 1968;574-9.

119. Sarto F, Rossi A, Toffanin R, Mafessanti M, Camposanpiero A. Indagine Clinico-Radiografica in 119 soggetti esposti all' asbesto: significato della ricerca delle placche pleuriche fibrose [Clinical and radiological survey of 119 asbestos workers: importance of detecting fibrous pleural plaques]. Med Lav 1982;1:45-57.

120. Jones RN, Diem JE, Hughes J, Hammad YY, Glindmeyer HW, Weill H. Progression of asbestos effects: a prospective longitudinal study of chest radiographs and lung function. $\mathrm{Br}$ J Ind Med 1989;46:97 — 105 .

121. McMillan CHG, Rossiter CE. Development of radiological and clinical evidence of parenchymal fibrosis in men with non-malignant asbestos-related pleural lesions. Br J Ind Med 1982;39:54-9.

122. Schwartz DA. New developments in asbestos-induced pleural disease. Chest 1991;99:191-8.

123. Schwartz DA, Fuoprtes LJ, Galvin JR, Burmeister LF, Schmidt LE, Lesitikow BN, et al. Asbestos-induced pleural fibrosis and impaired lung function. Am Rev Respir Dis $1990 ; 141: 321-6$

124. Sison R, Hruban R, Moore W, Kuhlman J, Wheeler P, Hutchins G. Pulmonary disease associated with pleural "asbestos" plaques. Chest 1989;95:831-5.

125. Smith DD. Plaques, cancer, and confusion. Chest 1994; 105:8-9.

126. Weiss W. Asbestos-related plaques and lung cancer. Chest 1993;103:1854-9.

127. Edelman DE. Asbestos exposure, pleural plaques and the risk of lung cancer. Int Arch Occup Environ Health 1988;60: $389-93$.

128. Hillerdal G, Nöu E. Occupation and bronchial carcinoma. Scand J Respir Dis 1979;60:76-82

129. Hillerdal G. Lung cancer: is the etiology changing? Cancer Detect Prev 1981;4:319-25.

130. Hillerdal G, Karlén E, Åberg T. Tobacco consumption and asbestos exposure in patients with lung cancer: a three-year prospective study. Br J Ind Med 1983;40:380-3.

131. Hertzog P, Toty L, Personne C, Roujeau J. Plaques pleurales, parietales, fibrohyalines. J Fr Med Chir Thor 1972;26:5970.

132. Toty L, Hertzog P, Personne C, Bakdach H. Thoracotomies et plaques pleurales fibro-hyalines. Rev Fr Mal Respir 1976; suppl 2 au Tome 4:93-6.

133. Harber P, Mohensifar Z, Oren A, Lew M. Pleural plaques and asbestos-associated malignancy. J Occup Med 1987;29: $641-4$.

134. Kiviluoto R, Meurman LO, Hakama M. Pleural plaques and neoplasia in Finland. Ann NY Acad Sci 1979;330:31-3.

135. Partanen T, Nurminen H, Zitting A, Koskinen H, Wiikeri M, Ahlman K. Localized pleural plaques and lung cancer. Am J Ind Med 1992;22:185—92.

136. Nurminen M, Tossavainen A. Is there an association between pleural plaques and lung cancer without asbestosis?. Scand J Work Environ Health 1994;20:62-4.

137. Kannerstein M, Churg J. Pathology of carcinoma of the lung associated with asbestos exposure. Cancer 1972;30:14-21.

138. Karjalainen A, Anttila S, Heikkilä L, Kyyrönen P, Vainio H. Lobe of origin in lung cancer among asbestos-exposed patents with or without diffuse interstitial fibrosis. Scand $\mathbf{J}$ Work Environ Health 1993;19:102-7.

139. Whitwell F, Newhouse ML, Bennett DR. A study of the histological cell types of lung cancer in workers suffering from asbestosis in the United Kingdom. Br J Ind Med 1974; 31:298-303

140. Mollo F, Pira E, Piolatto G, Bellis D, Burlo P, Andreozzi A, et al. Lung adenocarcinoma and indicators of asbestos exposure. Int J Cancer 1995;60:289-93.

141. Johansson L, Albin M, Jakobsson K, Mkozky Z. Histological type of lung carcinoma in asbestos cement workers and matched controls. Br J Ind Med 1992;49:626-30.

142. Vena JE, Byers TE, Cookfair D, Swanson M. Occupation and lung cancer risk: an analysis by histologic subtypes. Cancer 1985;56:910-7.

143. Kjuus H, Langård S, Skjærven R. A case-referent study of lung cancer, occupational exposures and smoking: III. etio- 
logic fraction of occupational exposures. Scand J Work Environ Health 1986;12:210-5.

144. Raffn E, Lynge E, Korsgard B. Incidence of lung cancer by histological type among asbestos cement workers in Denmark. Br J Ind Med 1993;50:85-9.

145. Imbernon E, Goldberg M, Bonenfant S, Chevalier A. Guénel P, Vatré R, Dehaye J. Occupational respiratory cancer and exposure to asbestos: a case-control study in a cohort of workers in the electricity and gas industry. Am J Ind Med 1995;28:339-52.

146. De Vos Irvine H, Lamont DW, Hole DJ, Gillis CR. Asbestos and lung cancer in Glasgow and the west of Scotland. Br Med J 1993;306:1503-6.

147. Blot WJ, Harrington JM, Toledo A, Hoover R, Heath CW, Fraumeni JF. Lung cancer after employment in shipyards during World War II. N Engl J Med 1978;299:620-4.

148. Järvholm B, Larsson S, Hagberg S, Olling S, Ryd W, Torén K. Quantitative importance of asbestos as a cause of lung cancer in a Swedish industrial city: a case-referent study. Eur
Respir J 1993;6:1271-5.

149. Bovenzi M, Stanta G, Antiga GL, Peruzzo P, Cavallieri F Occupation and lung cancer risk in Trieste, Italy. Med Lav 1992;83:338-48.

150. Vilkman S, Lahdensuo A, Mattila J, Tossavainen A, Tuomi T. Asbestos exposure according to different exposure indices among Finnish lung cancer patients. Int Arch Occup Environ Health 1993;65:269-74.

151. Abraham JL. Asbestos inhalation, not asbestosis, causes lung cancer. Am J Ind Med 1994;26:839— 42.

152. Pott $F$. Neoplastic findings in experimental studies and conclusions for fiber carcinogenesis in humans. Ann NY Acad Sci 1991;643:205-18.

153. Mossman BT, Kessler JB, Ley BW, Craighead JE. Interaction of crocidolite asbestos with hamster respiratory mucosa in organ culture. Lab Invest 1977;36:131—9.

Received for publication: 28 October 1996 